JIPS, Vol. 2 No. 2

Halaman: 160 - 179

Desember 2021
Jurnal Inovasi Pembelajaran di Sekolah

DOI: 10.51874/jips.v2i2.25

ISSN 2774-9363 (Cetak)

ISSN 2774-9746 (Online)
JIPS

Jurnal Inovasi Pembelajaran di Sekolah

\title{
Mini Workshop Sebagai upaya Peningkatan Profesionalitas Guru dalam Menyusun Perangkat Pembelajaran di SDN Dadapsari
}

\author{
Ainul Churotin \\ SDN Dadapsari Semarang \\ dadapsarisd@gmail.com
}

\begin{abstract}
The phenomenon that occurs in the teachers of SDN Dadapsari Korsatpen North Semarang, Semarang City, the number of subject matter requires teachers to compete to spend the target material so that they pay less attention to learning devices that should be their duties. of the 15 teachers, there are 10 or $67 \%$ of teachers who have not achieved the competence, while the remaining 5 teachers or $33 \%$ of teachers have achieved the desired competence. Teachers have not been able to compile learning tools because teachers do not understand how to arrange good learning tools. This is where the importance of supervision from the principal to the teacher by conducting mini workshops. This study is intended to answer the following problems: 1) How is the implementation of a mini workshop to improve teacher professionalism in compiling learning tools at SDN Dadapsari Korsatpen Semarang Utara, Semarang city for the 2020/2021 academic year?. 2) Is there an increase in teacher professionalism in compiling learning tools after a mini workshop was held at SDN Dadapsari Korsatpen North Semarang, Semarang city in the 2020/2021 academic year?. These problems are discussed through classroom action research which is carried out through 2 cycles with each cycle the stages are planning, action, observation and reflection. The results showed that: 1) The implementation of a mini workshop to improve teacher professionalism in compiling learning tools at SDN Dadapsari Korsatpen North Semarang, Semarang city in the 2020/2021 academic year was carried out by providing material to teachers on how to develop good learning tools, giving examples of reels, inviting the teacher to practice and discuss preparing a good device and the results are discussed together and the results of the learning tools carried out by the teacher are assessed and if errors are found, they are corrected. 2) The implementation of mini workshops can increase the professionalism of teachers at SDN Dadapsari Korsatpen North Semarang, Semarang City in the 2020/2021 academic year in compiling learning tools, this can be seen from the increase in the results of teacher professionalism in classroom administration management per cycle where in the first cycle there are 10 teachers or $67 \%$ and in the second cycle there were 14 students or $93 \%$. These results indicate that these results are in line with expectations. An increase also occurred in teacher activities in participating in mini workshops where in the first cycle there were 11 students or $77 \%$ and in the second cycle there were 14 students or $93 \%$. The increase is the implementation of mini workshops to be one effective way for school principals in improving the ability of teachers in preparing learning tools
\end{abstract}

Keywords: Mini Workshop, Improvement, Professionalism, Teachers, Learning Tools

\begin{abstract}
ABSTRAK
Fenomena yang terjadi pada guru SDN Dadapsari Korsatpen Semarang Utara Kota Semarang banyaknya materi pelajaran menuntut guru berlomba untuk menghabiskan target materi sehingga kurang memperhatikan perangkat pembelajaran yang seharusnya menjadi tugasnya. dari 15 guru, ada 10 atau $67 \%$ guru yang belum mencapai kompetensi, sedangkan sisanya 5 guru atau $33 \%$ guru yang sudah mencapai kompetensi yang dikehendaki. Guru belum mampu menyusun perangkat pembelajaran disebabkan karena guru belum paham cara menyusun perangkat pembelajaran yang baik. Disinilah pentingnya supervisi dari kepala sekolah pada guru dengan melakukan workshop mini. Studi ini dimaksudkan untuk menjawab permasalahan: 1) Bagaimanakah pelaksanaan mini workshop bagi peningkatan profesionalitas guru dalam menyusun perangkat pembelajaran di SDN Dadapsari Korsatpen Semarang Utara kota Semarang tahun Pelajaran 2020/2021?. 2) Adakah peningkatan profesionalitas guru dalam menyusun perangkat pembelajaran setelah dilaksanakan mini workshop di SDN Dadapsari Korsatpen Semarang Utara kota Semarang tahun Pelajaran 2020/2021?. Permasalahan tersebut di bahas melalui penelitian tindakan kelas yang dilakukan melalui 2 siklus dengan setiap siklus tahapannya adalah perencanaan, tindakan, observasi dan refleksi. Hasil penelitian menunjukkan bahwa: 1)
\end{abstract}

Hal. 160 
Pelaksanaan mini workshop bagi peningkatan profesionalitas guru dalam menyusun perangkat pembelajaran di SDN Dadapsari Korsatpen Semarang Utara kota Semarang tahun Pelajaran 2020/2021 dilakukan dengan memberikan materi kepada guru tentang cara menyusun perangkat pembelajaran yang baik, memberikan contoh reeiel, mempersilahkan guru untuk latihan dan berdiskusi menyusun perangkat yang baik dan hasilnya diskusikan bersama dan hasil perangkat pembelajaran yang dilakukan guru dinilai dan jika ditemukan kesalahan maka dilakukan perbaikan. 2) Pelaksanaan mini workshop dapat meningkatkan peningkatan profesionalitas guru SDN Dadapsari Korsatpen Semarang Utara kota Semarang tahun Pelajaran 2020/2021dalam menyusun perangkat pembelajaran, hal ini dapat dilihat dari peningkatan hasil profesionalias guru dalam pengelolaan administrasi kelas per siklus dimana pada siklus I ada 10 guru atau 67\% dan pada siklus II ada 14 siswa atau 93\%. Hasil tersebut menunjukkan bahwa hasil tersebut sesuai dengan yang diharapkan. Peningkatan juga terjadi pada aktivitas guru dalam mengikuti mini worskhsop dimana pada siklus I ada 11 siswa atau 77\% dan siklus II ada 14 siswa atau 93\%. Peningkatan tersebut pelaksanaan mini workshop menjadi salah satu cara yang efektif bagi kepala sekolah dalam meningkatkan kemampuan guru dalam menyusun perangkat pembelajaran

Kata kunci: Mini Workshop, Peningkatan, Profesionalita, Guru, Perangkat Pembelajaran

\section{PENDAHULUAN}

Kepala sekolah adalah sebagai seorang pemimpin yang ditugaskan untuk mengelola sekolah sangat penting peranannya dalam pengembangan sekolah. Kepala sekolah yang berhasil adalah apabila mereka memahami keberadaan sekolah sebagai organisasi yang kompleks, serta mampu melaksanakan peranan kepala sekolah sebagai seorang yang diberi tanggung jawab untuk memimpin sekolah (Wahyosumidjo, 2011: 81). Bahkan lebih dari itu studi keberhasilan kepala sekolah menunjukkan bahwa kepala sekolah adalah yang menentukan titik pusat dan irama suatu sekolah.

Peranan kepala sekolah sebagai pemimpin mencerminkan tanggung jawab kepala sekolah untuk menggerakkan seluruh sumber daya yang ada di sekolah, sehingga lahir etos kerja dan produktivitas yang tinggi dalam mencapai tujuan. Fungsi kepemimpinan ini amat penting sebab di samping sebagai penggerak juga berperan untuk melakukan kontrol segala aktivitas guru (dalam rangka peningkatan profesional mengajar), guru dan siswa sekaligus untuk meneliti persoalan-persoalan yang timbul di lingkungan sekolah (Wahyosumidjo, 2011: 90). Dalam usaha peningkatan kualitas sumber daya pendidikan, guru mempunyai peran yang sangat penting, bahkan sebagian besar terletak pada kegiatan guru dalam proses pembelajaran siswa ke arah tercapainya tujuan pendidikan. Karena peranannya itu, maka wajar dan bahkan menjadi suatu keharusan untuk kepala sekolah untuk mendorong semangat hidup dan motivasi kerja para guru dalam melaksanakan profesinya yang pada gilirannya akan mendorong peningkatan mutu pendidikan.

Pekerjaan profesional memerlukan keahlian khusus. Dengan keahlian khusus ini diharapkan sebuah pekerjaan akan dapat berhasil, karena orang yang mengerjakan memiliki kemampuan sesuai dengan tuntutan pekerjaannya. Oleh karena itu di sini peran Kepala 
sekolah sangat penting untuk menciptakan guru yang bermutu, di samping sebagai administrator yang pandai mengatur dan bertanggung tentang kelancaran tujuan sekolah sehari-hari, juga adalah seorang supervisor (Purwanto, 2010: 80-81).

Fenomena yang terjadi pada guru SDN Dadapsari Korsatpen Semarang Utara kota Semarang banyaknya materi pelajaran menuntut guru berlomba untuk menghabiskan target materi sehingga kurang memperhatikan perangkat pembelajaran yang seharusnya menjadi tugasnya, perangkat pembelajaran menajdi satu perencanaan penting dalam setiap pembelajaran yang nantinya akan mengarahkan proses pembelajaran yang dilakukan guru tearah dan sistematis, berdasarkan pra riset awal penelitian pada guru-guru SDN Dadapsari Korsatpen Semarang Utara kota Semarang, ditemukan fakta bahwa kemapuan guru dalam menyusun perangkat pembelajaran masih rendah. Hal ini dapat dilihat dari 15 guru, ada 10 atau $67 \%$ guru yang belum mencapai kompetensi, sedangkan sisanya 5 guru atau $33 \%$ guru yang sudah mencapai kompetensi yang dikehendaki. Kesulitan yang dialami guru dalam menyusun perangkat pembelajaran dapat diidentifikasi beberapa kelemahan antara lain: kurang lengkapnya perangkat pembelajaran yang disusun oleh guru, guru tidak rutin dalam menyusun Rencana Pelaksanaan Pembelajaran (RPP), pembelajaran yang dilaksanakan oleh guru kurang sesuai dengan Rencana Pelaksanaan Pembelajaran (RPP) yang disusun, sebagian guru dalam menyusun silabus dan RPP hanya meng-copy paste dari teman maupun internet serta hanya menyusun perangkat pembelajaran ketika akan disupervisi oleh kepala sekolah.

Kecenderungan tersebut disebabkan guru enggan menyusun perangkat pembelajaran karena banyak tugas yang harus dikerjakan sehingga dengan menyusun perencanaan pembelajaran dapat menggagu proses belajar mengajar di kelas. Guru belum mampu menyusun perangkat pembelajaran disebabkan karena guru belum paham cara menyusun perangkat pembelajaran yang baik. Disinilah pentingnya supervisi dari kepala sekolah pada guru di SDN Dadapsari Korsatpen Semarang Utara kota Semarang dengan melakukan workshop mini, karena guru SDN Dadapsari Korsatpen Semarang Utara kota Semarang jarang mendapatkan kesempatan mengikuti workshop, lokakarya, diskusi panel mengenai penyusunan perangkat pembelajaran.

Workshop mini dalam pendidikan adalah suatu kegiatan belajar kelompok yang terdiri dari petugas-petugas pendidikan yang memecahkan problema yang dihadapai melalui percakapan dan bekerja secara kelompok maupun bersifat perorangan (Sahertian, 2010:121). Dengan mengikuti kegiatan workshop guru dapat memecahkan masalah dan bertukar pikiran untuk mendapatkan solusi dari masalah pembelajaran yang sedang dihadapi, khususnya masalah penyusunan perangkat pembelajaran. 
Kegiatan workshop mini memiliki keunggulan dalam penyelenggara-annya yaitu: a) memberi kebebasan berargumen kepada peserta workshop dan pemakalah; b) memberi peluang melibatkan banyak peserta; c) menyerap informasi sebanyak mungkin untuk suatu hasil atau perubahan konsep semula sehingga ide pemakalah akan diuji dan mendapat tanggapan tentang kelebihan dan kekurangan dari ide para pemakalah; d) dapat digunakan sebagai referensi bagi pengamat dan pemegang kebijakan baik masyarakat umum dan pemerintah (Sumarno, 2012:61). Dalam kegiatan workshop Mini, guru dapat memecahkan masalah yang dihadapi di kelas khususnya mengenai penyusunan perangkat pembelajaran. Guru akan dibimbing dan diberikan materi mengenai konsep, prinsip dan prosedur penyusunan perangkat pembelajaran oleh kepala sekolah sebagai manajer di sekolah. Dengan pelaksanaan workshop Mini diharapkan kemampuan guru dalam menyusun perangkat pembelajaran dapat meningkat.

Berdasarkan latar belakang di atas peneliti tertarik untuk mengadakan penelitian tindakan sekolah tentang "Mini Workshop Sebagai Upaya Peningkatan Profesionalitas Guru dalam Menyusun Perangkat Pembelajaran di SDN Dadapsari Korsatpen Semarang Utara kota Semarang tahun Pelajaran 2020/2021"

\section{KAJIAN TEORI}

Kepala sekolah merupakan motor penggerak, penentu arah kebijakan sekolah yang akan menentukan bagaimana tujuan-tujuan dan pendidikan pada umumnya direalisasikan bagaimana (Mulyasa, 2013: 126). Dalam hal ini ia memegang peranan terpenting, yakni sebagai penanggung jawab semua kegiatan yang terdapat dalam sekolah. Mulai dari relokasi kepegawaian sampai hal yang terkecil, seperti penyiapan syllabus dalam proses belajarmengajar.

Menurut Slamet PH, ada 17 ciri kepala sekolah yang tangguh. Ke tujuh belas ciri tersebut adalah memiliki (1) visi-misi dan strategi (2) kemampuan mengkoordinasikan dan menyerasikan sumberdaya (3) kemampuan mengambil keputusan (4) toleransi terhadap perbedaan setiap orang (5) memobilisasi sumber daya (6) menerangi musuh-musuh kepala sekolah (7) menggunakan input manajemen (9) menjalankan perannya yang berdimensi banyak seperti pemimpin, manajer pendidikan dan lain-lain, (10) melaksanakan dimensidimensi tugas, proses, lingkungan dan ketrampilan personal (11) menjalankan gejala empat serangkai yaitu merumuskan sasaran, melakukan analisis SWOT, dan mengupayakan langkah-langkah untuk meniadakan persoalan , (12) menggalang team work yang cerdas dan kompak (13) mendorong kegiatan-kegiatan kreatif (14) menciptakan sekolah belajar (15) 
menerapkan manajemen berbasis sekolah (16) memusatkan perhatian pada pengelolaan proses belajar mengajar dan (17) memperdayakan sekolah (Slamet, 2012: 2).

Jadi kepemimpinan kepala sekolah yaitu seseorang pemimpin sekolah yang tidak hanya aktif berkecimpung dalam dunia pendidikan akan tetapi sosialisasi yang baik terhadap masyarakat sekitar harus dilakukan juga. Sebagaimana kedudukan yang sama seperti yang lainnya, sebab tidak hanya mahluk individual ansich sekaligus makhluk sosial.

Dalam satuan pendidikan, kepala sekolah menduduki dua jabatan penting untuk bisa menjamin kelangsungan proses pendidikan sebagaimana yang telah digariskan oleh peraturan perundang-undangan. Pertama, kepala sekolah dalam pengelola pendidikan di sekolah secara keseluruhan. Kedua, Kepala Sekolah adalah pemimpin formal di sekolahnya (Anwar, 2013: 86). Sebagai pengelola pendidikan, berarti kepala sekolah bertanggungjawab terhadap keberhasilan penyelenggaraan kegiatan pendidikan dengan cara melaksanakan administrasi sekolah dengan seluruh substansinya. Di samping itu, kepala sekolah bertanggungjawab terhadap kualitas sumber daya manusia yang ada agar mereka mampu menjalankan tugastugas pendidikan.

Sebagai pengelola, kepala sekolah memiliki tugas untuk mengembangkan kinerja para personal (terutama para guru) ke arah profesionalitas yang diharapkan (Anwar, 2013: 87). Sebagai pemimpin formal, kepala sekolah bertanggungjawab atas tercapainya tujuan pendidikan melalui upaya menggerakkan para bawahan ke arah pencapaian tujuan pendidikan yang telah ditetapkan. Dalam hal ini kepala sekolah berfungsi sebagai koordinator yang mampu memberikan instruksi dan pengarahan serta mampu melaksanakan tugas-tugas yang menjadi tanggungjawabnya, dan ini menjadi bagian tidak terpisahkan dari kepemimpinannya.

Dalam paradigma baru manajemen pendidikan, kepala sekolah sedikitnya harus mampu berfungsi sebagai educator, administrator, supervisor, leader, innovator, dan motivator (Mulyasa, 2013: 98).

Kepala sekolah merupakan jabatan seorang yang berwenang sebagai pimpinan dalam suatu sekolah, dimana ia dituntut agar dapat mengelola dan mengembangkan programprogram pendidikan di sekolah sesuai dengan kerangka dasar yang telah ditetapkan. Dengan demikian kepala sekolah menempati posisi sebagai penggerak pada orang-orang yang ia pimpin dan menjadi tanggung jawab, agar tujuan yang telah ditetapkan dapat tercapai dengan baik. Kepada sekolah sebagai seorang supervisor merupakan satu-satunya orang yang dapat membantu perkembangan anggota-anggota atau stafnya dalam usaha meningkatkan mutu pendidikan di sekolah. 
Sehubungan dengan peranan kepala sekolah, maka lahirlah tanggung jawab sebagai pemimpin kepala sekolah. Sebagai pemimpin pendidikan dan pengajaran, akan selalu berhadapan dengan kenyataan-kenyataan yang ada, yaitu tentang sukses atau tidaknya kegiatan pembinaan, bimbingan dan layanan yang dapat diusahakan nya, yang semuanya diarahkan pada usaha perbaikan pada situasi pendidikan [ada umumnya dan khususnya pada peningkatan mutu pengajaran yang dilaksanakan guru serta aktifitas belajar murid di sekolah.

Pencapaian mutu pendidikan dan pengajaran ditekankan pada efektifitas proses kegiatan belajar mengajar, sehingga sebagai pemimpin sekolah harus mampu memahami bawahannya, dan dapat menempatkan dirinya sebagai seorang pemimpin sekolah. Seorang pemimpin pendidikan dan pengajaran di sekolah yang penuh tanggung jawab, senantiasa menambahkan mutu pendidikan dan pengajaran yang dikelola, sehingga ia selalu berusaha untuk dapat merealisasikan dan melestarikan terhadap tugas yang dibebankan kepadanya.

Kualitas pendidikan dan pengajaran itu dapat direalisasikan apabila sebagai pemimpin sekolah dapat menyadarkan para guru dalam melaksanakan proses belajar mengajar, yang diawali dengan menyadarkan tugas dan fungsi serta kewajiban kepala sekolah itu sendiri.

Agar pembinaan tersebut dapat dilakukan dengan baik, perlu dipedomani prinsipprinsip pembinaan guru. Yang dimaksud dengan prinsip adalah sesuatu yang harus dipedomani dalam suatu aktivitas.

Workshop adalah suatu kegiatan belajar kelompok yang terjadi dari sejumlah pendidik yang sedang memecahkan masalah melalui percakapan dan bekerja secara kelompok (Sagala, 2010: 214). Dalam workshop disediakan ruangan khusus yang dilengkapi dengan sumber-sumber pustaka dan berbagai peralatan yang digunakan sebagai media pembelajaran sehingga guru dapat bekerja dan belajar dalam ruangan itu. Tujuan dari workshop ialah untuk memperoleh informasi melalui pengalaman langsung dan saling menyampaikan informasi, untuk mendengarkan ceramah-ceramah, melihat demonstrasidemonstrasi, mendiskusi-kan berbagai aspek topik, mempelajari, mengerjakan, mempraktekkan, dan mengevaluasinya (Sumarno, 2012:56).

Sedangkan workshop mini merupakan temapt berkumpul orang-orang dalam skala kecil seperti sekolah yang memiliki minat dan keahlian yang sama pada bidang tertentu,, mereka akan berkumpul untuk dapat mengikuti arahan ahli untuk membahas suatu permasalahan. Dalam workshop mini di sekolah tersebut dapat dilakukan berbagai pelatihan dari program rutin dan program pengembangan. Program rutin sekurang-kurangnya terdiri dari: a) Diskusi permasalahan pembelajaran; b) Penyusunan silabus, program semester, dan 
Rencana Program Pembelajaran; c) Analisis kurikulum; d) Penyusunan instrumen evaluasi pembelajaran; e) Pembahasan materi dan pemantapan menghadapi Ujian Nasional.

Tanggung jawab dalam mengembangkan profesi pada dasarnya ialah tuntutan dan panggilan untuk selalu mencintai, menghargai, menjaga dan meningkatkan tugas dan tanggung jawab profesinya. Guru harus sadar bahwa dalam melaksanakan tugas selalu dituntut untuk bersungguh-sungguh. guru sebagai tenaga profesional, tentulah tidak lepas dari arti profesionalitas itu sendiri. Secara istilah adalah "Suatu pekerjaan yang memerlukan pendidikan lebih lanjut dalam ilmu (science) dan teknologi yang digunakan sebagai perakat dasar untuk diimplementasikan, dalam berbagai kegiatan yang bermanfaat (Sardiman, 2006: 131).

Profesionalitas itu merujuk pada derajat penampilan seseorang sebagai profesional atau penampilan suatu pekerjaan bangsa suatu profesi, ada yang profesionalitasnya tinggi, sedang dan rendah. Profesionalitas juga mengacu kepada sikap dan komitmen anggota profesi untuk bekerja berdasarkan standar yang tinggi dan kode etik dan profesinya (Supriadi, 1999: 95).

Guru merupakan tenaga profesional yang bertugas merencanakan dan melaksanakan proses pembelajaran, menilai hasil pembelajaran, melakukan pembimbingan dan pelatihan, serta melakukan penelitian dan pengabdian kepada masyarakat (Undang-Undang Republik Indonesiai, Nomor 20 Tahun 2003: 23). Guru adalah pendidik profesional dengan tugas utama mendidik, mengajar, membimbing, mengarahkan, melatih, menilai dan mengevaluasi peserta didik pada pendidikan anak usia dini jalur pendidikan formal, pendidikan dasar, dan pendidikan menengah (Undang-Undang Republik Indonesia, Nomor 14 Tahun 2005: 52).

Sebagai guru profesional guru harus dapat mengelola perangkat pembelajaran adalah kemampuan mengelola pembelajaran peserta didik, yang meliputi: penyusunan rencana pembelajaran, pelaksanaan interaksi belajar mengajar, penilaian prestasi belajar peserta didik. (Tim Penyusun Undang-undang No. 14/2005: 48)

Perangkat pembelajaran menurut KBBI adalah alat perlengkapan yang digunakan dalam proses atau cara yang dapat menjadikan orang atau makhluk hidup belajar. Perangkat pembelajaran merupakan hal-hal yang disiapkan oleh guru untuk melakukan suatu proses pembelajaran. Perangkat pembelajaran dapat meliputi: Rencana Pelaksanaan Pembelajaran (RPP), Lembar Kegiatan Siswa (LKS), dan alat peraga.

Dalam Permendikbud Nomor 65 Tahun 2013 mengenai Standar Proses, perangkat pembelajaran pada Kurikulum 2013 ditekankan pada pendekatan scientific (ilmiah) dengan pembelajaran berbasis penemuan/penyelidikan (discovery/inquiry learning). Selain itu, 
perencanaan pembelajaran pada Kurikulum 2013 yang dirancang dalam bentuk RPP, LKS serta alat peraga yang mengacu pada Standar Isi.

Dalam penerapannya, perangkat pembelajaran terdiri dari berbagai komponen bergantung kepada kebutuhan masing-masing guru. Namun dalam penelitian ini, perangkat pembelajaran yang dimaksud adalah buku siswa, lembar kegiatan siswa, rencana pelaksanaan pembelajaran, dan tes hasil belajar.

Perangkat pembelajaran merupakan suatu persiapan yang disusun oleh guru agar pelaksanaan dan evaluasi pembelajaran dapat dilakukan secara sistematis dan memperoleh hasil seperti yang diinginkan, meliputi: analisis minggu efektif, program tahunan, program semester, silabus, rencana pelaksanaan pembelajaran (RPP), lembar kegiatan siswa (LKS), instrumen evaluasi, dan kriteria ketuntasan minimum/KKM (Nazarudin, 2011:113).

Silabus adalah pembelajaran pada suatu dan/atau kelompok mata pelajaran/tema tertentu yang mencakup standar kompetensi, kompetensi dasar, materipokok pembelajaran, kegiatan pembelajaran, dan indikator pencapaian kompetensi untuk penilaian (Sanjaya, 2010:55).

Rencana Pelaksanaan Pembelajaran (RPP) adalah program perencanaan yang disusun sebagai pedoman pelaksanaan pembelajaran untuk setiap kegiatan proses pembelajaran (Sanjaya, 2010:60).

Sebuah perencanaan pembelajaran satuan pembelajaran yang baik harus memenuhi kriteria yaitu kemampuan dasar dan materi harus mengacu pada silabus, proses belajar harus memberikan pengalaman yang bermakna bagi siswa, terdapat keselarasan antara kemampuan dasar, materi dan alat penilaian, dapat dilaksanakan dan mudah dipahami (Winarno dan Djuniarto, 2003: 9).

Bahan ajar adalah seperangkat sarana atau alat pembelajaran yang berisikan materi pembelajaran, metode, batasan-batasan, dan cara mengevaluasi yang didesain secara sistematis dan menarik dalam rangka mencapai tujuan yang diharapkan, yaitu mencapai kompetensi atau subkompetensi dengan segala kompleksitasnya (Widodo \& Jasmadi, 2008:40).

Salah satu manfaat perencanaan pembelajaran sebagai dasar alat kontrol dan petunjuk arah kegiatan dalam mencapai tujuan (Sanjaya, 2010:32). Bila guru tidak menyusun perangkat pembelajaran, dapat dipastikan pembelajaran yang diajarkan tidak memiliki arah yang jelas sehingga dapat berpengaruh pada hasil belajar siswa di kelas. Sebaliknya bila guru menyusun perangkat pembelajaran dengan baik, pembelajaran yang diajarkan pada siswa memiliki tujuan yang jelas dan dipastikan hasil belajar siswa dapat meningkat. 
Dengan demikian, perangkat pembelajaran banyak tergantung kepada kompetensi guru dalam mengembangkannya, karena tugas guru berkaitan dengan melaksanakan pembelajaran yang menjadi tanggung jawabnya. Oleh karena itu, diperlukan perangkat pembelajaran yang dapat mencapai keefektifan pembelajaran yang dilaksanakan. Dengan perangkat pembelajaran guru akan mantap melaksana-kan pembelajaran di kelas. Perencanaan yang matang dapat menimbulkan banyak inisiatif dan daya kreatif guru dalam mengajar dan dapat meningkatkan interaksi belajar mengajar antara guru dan siswa, serta pada akhirnya dapat meningkatkan hasil belajar siswa di kelas.

Salah satunya memecahkan masalah yang berkaitan penyusunan perangkat pembelajaran meliputi: silabus, RPP, bahan ajar, dan evaluasi pembelajaran. Program pengembangan tersebut, salah satunya dapat dikembangkan melalui kegiatan workshop mini. Workshop mini bagi penyusunan perangkat pembelajaran bagi para kepala sekolah ini akan mengupayakan beberapa solusi pemecahan masalah sesuai dengan prioritas masalah. Dengan mengikuti kegiatan workshop guru dapat memecahkan masalah dan bertukar pikiran untuk mendapatkan solusi dari masalah pembelajaran yang sedang dihadapi, khususnya masalah penyusunan perangkat pembelajaran. Hal tersebut sesuai dengan pendapat Sumarno (2012:56), bahwa kegiatan workshop bertujuan untuk memperoleh informasi melalui pengalaman langsung dan saling menyampaikan informasi. Lebih jelasnya peneliti gambarkan dalam gambar berikut: 


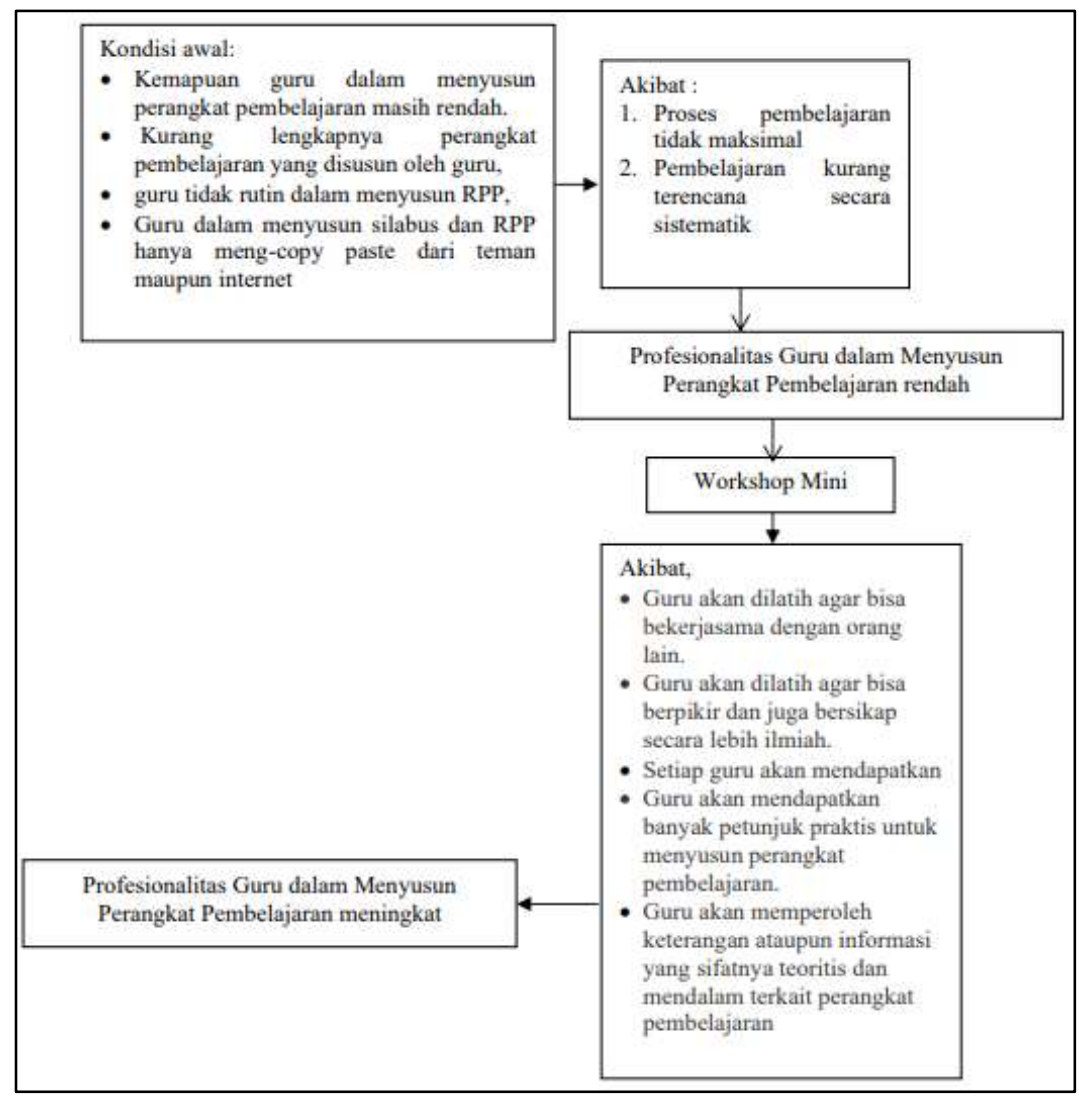

Gambar 1. Kerangka Berpikir

Hipotesis tindakan dalam penelitian ini adalah terjadai pelaksanaan mini workshop dapat meningkatkan profesionalitas guru dalam menyusun perangkat pembelajaran di SDN Dadapsari Korsatpen Semarang Utara kota Semarang tahun Pelajaran 2020/2021.Tempat Penelitian

\section{METODE PENELITIAN}

Tempat penelitian SDN Dadapsari Korsatpen Semarang Utara kota Semarang tahun Pelajaran 2020/2021. Penelitian ini dilakukan pada tanggal 27 Januari 2021 sampai 31 Maret 2021. Adapun subjek dalam penelitian ini adalah seluruh guru SDN Dadapsari Korsatpen Semarang Utara kota Semarang tahun Pelajaran 2020/2021sejumlah 15 guru. Variabel penelitian terdiri atas variabel bebas dan variabel terikat. Variabel bebas (yang mempengaruhi) dalam penelitian ini adalah Mini Workshop sedangkan variabel terikatnya (yang dipengaruhi) adalah Profesionalitas Guru dalam Menyusun Perangkat Pembelajaran.

Rancangan tindakan dilakukan dengan prosedur penelitian berdasarkan pada prinsip Kemmis dan Taggart yang mencakup kegiatan sebagai berikut: (1) perencanaan (planning), (2) pelaksanaan tindakan (action), 3) observasi (observation), (4) refleksi (reflection) atau evaluasi. Keempat kegiatan ini berlangsung secara berulang dalam bentuk siklus. 


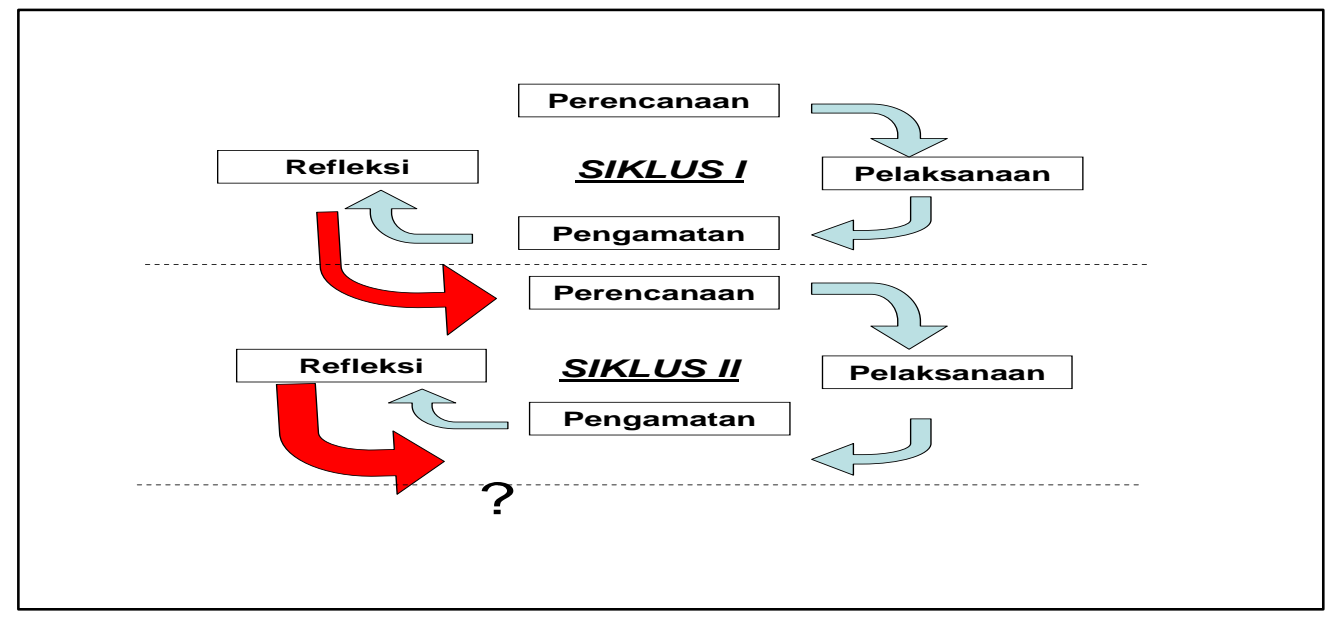

Gambar 2. Prosedur Penelitian

Teknik Pengumpulan Data

\section{Metode Observasi}

Metode pengamatan (observasi), cara pengumpulan datanya terjun langsung ke lapangan terhadap objek yang diteliti, populasi (sampel) (Margono, 2010: 158). Observasi dilakukan untuk mengamati aktivitas tutor dan peserta atau guru dalam seminar mini. Observasi penelitian ini dilakukan dengan cara melakukan pengamatan dan pencatatan mengenai pelaksanaan mini workshop bagi peningkatan profesionalitas guru dalam menyusun perangkat pembelajaran dan partisipasi peserta selama proses seminar mini berlangsung berlangsung.

2. Metode Dokumentasi

Metode dokumentasi yaitu mencari data mengenai hal-hal atau variabel yang berupa catatan, buku, transkip, surat kabar majalah, prasasti, notulen rapat, legger, agenda dan sebagainya (Arikunto, 2010: 206). Metode ini digunakan untuk memperoleh data dokumen tentang perangkat pembelajaran yang ada pada guru.

Alat pengumpulan data yang peneliti gunakan untuk menilai tingkat keberhasilan siswa adalah:

1. Lembar observasi

Lembar observasi adalah lembar pengamatan yang harus diisi oleh observer. Lembar observasi berisi tentang kegiatan tutor atau kepala sekolah dan aktifitas peseta atau guru dalam pelaksanaan mini workshop. 


\section{Instrumen Evaluasi}

Instrumen evaluasi adalah alat untuk memperoleh hasil yang telah sesuai dengan kenyataan yang dievaluasi. Sedang bentuk perangkat pembelajaran guu.

\section{Analisis Data}

1. Analisis deskriptif kualitatif

Analisis deskriptif kualitatif, artinya seluruh data yang terkumpul diolah secara non statistik untuk menggambarkan situasi hasil penelitian. Analisis ini digunakan untuk mengetahui aktivitas peserta didik selama proses pembelajaran (Sugiyono, 2013: 335).

2. Analisis kuantitatif

Untuk mengetahui keberhasilan klasikal digunakan rumus berikut:

$$
\text { Nilai }=\frac{\text { Skor yang dicapai }}{\text { Jumlah guru }} \times 100 \%
$$

Sedangkan untuk ketuntasan secara individu guru dengan rumus :

$$
\text { Nilai }=\frac{\text { Skor yang dicapai }}{\text { Skor Maksimal }} \times 100 \%
$$

Kriteria:

Baik Sekali (A) : $90<\mathrm{A} \leq 100$

Baik (B) $\quad: 70<\mathrm{B} \leq 89$

Cukup (C) $\quad: 60<\mathrm{C} \leq 79$

Kurang $(\mathrm{K}) \quad: \leq 60$

Sedangkan Untuk mengetahui tingkat keberhasilan penelitian tindakan sekolah ini apabila:

1. Meningkatnya profesionalitas guru dalam menyusun perangkat pembelajaran pada kategori baik dan baik sekali sebanyak $90 \%$.

2. Meningkatnya keaktifan belajar peserta didik pada kategori baik dan baik sekali sebanyak $90 \%$

\section{HASIL PENELITIAN}

\section{Siklus I}

Pelaksanaan siklus I dilakukan pada tanggal 27 Januari 2021. Berdasarkan hasil mini workshop ini peneliti menilai perangkat pembelajaran yang telah dilakukan guru. Untuk lebih jelasnya diperoleh data yang digambarkan dalam tabel dan diagram berikut:

Tabel 1. Profesionalitas Guru dalam Menyusun Perangkat Pembelajaran Siklus I 


\begin{tabular}{|c|c|c|c|}
\hline \multirow{2}{*}{ Kategori } & \multirow{2}{*}{ Angka } & \multicolumn{2}{|c|}{ Siklus I } \\
\cline { 3 - 4 } & & guru & $\%$ \\
\hline Baik Sekali & $90 \%-100 \%$ & 4 & $27 \%$ \\
Baik & $70 \%-89 \%$ & 6 & $40 \%$ \\
\hline Cukup & $50 \%-69 \%$ & 5 & $33 \%$ \\
Kurang & $\leq 49 \%$ & 0 & $0 \%$ \\
\hline \multicolumn{2}{|c|}{ Jumlah } & 24 & 15 \\
\hline
\end{tabular}

Dari tabel di atas dapat diketahui profesionalitas Guru dalam Menyusun Perangkat Pembelajaran pada siklus I dimana pada kategori baik sekali sebanyak 4 guru atau 27\%, kategori baik sebanyak 6 guru atau 40\%, kategori cukup sebanyak 5 guru atau 33\%, kategori kurang sebanyak 0 guru atau $0 \%$.

Setelah mengobservasi peserta atau guru selama proses pelaksanaan mini workshop dengan menggunakan instrumen observasi yang dipegang kolabolator di dapat nilai dari keaktifan peserta terutama yang terkait dengan keaktifan guru dalam mendengarkan penjelasan tutor, keaktifan guru dalam diskusi, dan keaktifan guru dalam mengerjakan tugas. Untuk lebih jelasnya diperoleh data yang digambarkan dalam tabel dan diagram berikut:

Tabel 2. Aktivitas guru dalam Mini Workshop Siklus I

\begin{tabular}{|c|c|c|c|}
\hline \multirow{2}{*}{$\begin{array}{c}\text { Jumlah } \\
\text { aktivitas }\end{array}$} & \multicolumn{2}{|c|}{ Siklus I } & \multirow{2}{*}{ Kategori } \\
\cline { 2 - 3 } & Guru & $\%$ & \\
\hline $14-16$ & 5 & $33 \%$ & Sangat Aktif \\
\hline $11-13$ & 6 & $40 \%$ & Aktif \\
\hline $8-10$ & 3 & $20 \%$ & Cukup \\
\hline $5-7$ & 1 & $7 \%$ & Kurang \\
\hline Jumlah & 32 & $100 \%$ & \\
\hline
\end{tabular}

Dari tabel di atas dapat diketahui aktivitas guru dalam mini workshop pada siklus I dimana pada kategori baik sekali sebanyak 6 guru atau 25\%, kategori baik sebanyak 9 guru atau 38\%, kategori cukup sebanyak 7 guru atau 29\%, kategori kurang sebanyak 2 guru atau $8 \%$. Sedangkan pengkategorian masing aspek dapat dilihat pada tabel sebagai berikut:

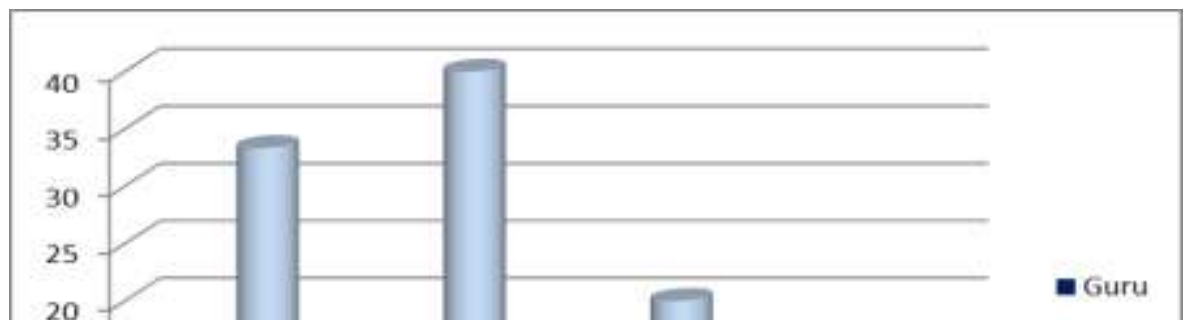

Hal. 172 
Gambar 1. Diagram Batang Mini Workshop Siklus I

Dari tabel dan diagram di atas menunjukkan aktivitas guru dalam mini workshop kurang baik dan perlu ada peningkatan tindakan dalam mini workshop yang dilakukan peneliti pada siklus berikutnya

\section{Siklus II}

Pelaksanaan siklus II dilakukan pada tanggal 22 Februari 2021. Berdasarkan hasil mini workshop ini peneliti menilai perangkat pembelajaran yang telah dilakukan guru. Untuk lebih jelasnya diperoleh data yang digambarkan dalam tabel dan diagram berikut:

Tabel 3. Profesionalitas Guru dalam Menyusun Perangkat Pembelajaran Siklus II

\begin{tabular}{|c|c|c|c|}
\hline \multirow{2}{*}{ Kategori } & \multirow{2}{*}{ Angka } & \multicolumn{2}{|c|}{ Siklus I } \\
\cline { 3 - 4 } & & Guru & $\%$ \\
\hline Baik Sekali & $90 \%-100 \%$ & 8 & $53 \%$ \\
Baik & $70 \%-89 \%$ & 6 & $40 \%$ \\
\hline Cukup & $50 \%-69 \%$ & 1 & $7 \%$ \\
Kurang & $\leq 49 \%$ & 0 & $0 \%$ \\
\hline \multicolumn{2}{|c|}{ Jumlah } & 15 & $100 \%$ \\
\hline
\end{tabular}

Dari tabel di atas dapat diketahui profesionalitas Guru dalam Menyusun Perangkat Pembelajaran pada siklus II dimana pada kategori baik sekali sebanyak 8 guru atau 53\% naik dari siklus I yaitu 4 guru atau 27\% naik, kategori baik sebanyak 6 guru atau $40 \%$ sama dengan siklus I, kategori cukup sebanyak 1 guru atau 7\% turun dari siklus I yaitu 5 guru atau $33 \%$. Sedangkan pengkategorian masing aspek dapat dilihat pada tabel sebagai berikut:

Setelah mengobservasi peserta atau guru selama proses pelaksanaan mini workshop dengan menggunakan instrumen observasi yang dipegang kolabolator di dapat nilai dari keaktifan peserta terutama yang terkait dengan keaktifan guru dalam mendengarkan 
penjelasan tutor, keaktifan guru dalam diskusi, dan keaktifan guru dalam mengerjakan tugas. Untuk lebih jelasnya diperoleh data yang digambarkan dalam tabel dan diagram berikut:

Tabel 4. Aktivitas guru dalam Mini Workshop Siklus II

\begin{tabular}{|c|c|c|c|}
\hline \multirow{2}{*}{$\begin{array}{c}\text { Jumlah } \\
\text { aktivitas }\end{array}$} & \multicolumn{2}{|c|}{ Siklus I } & \multirow{2}{*}{ Kategori } \\
\cline { 2 - 3 } & Guru & $\%$ & \\
\hline $14-16$ & 9 & $60 \%$ & Sangat Aktif \\
\hline $11-13$ & 5 & $33 \%$ & Aktif \\
\hline $8-10$ & 1 & $7 \%$ & Cukup \\
\hline $5-7$ & 0 & $0 \%$ & Kurang \\
\hline Jumlah & 15 & $100 \%$ & \\
\hline
\end{tabular}

Dari tabel di atas dapat diketahui aktivitas guru dalam mini workshop pada siklus II dimana pada kategori baik sekali sebanyak 9 guru atau 60\% naik dari siklus I yaitu 5 guru atau 33\%, kategori baik sebanyak 5 guru atau 33\% sama dengan siklus I, kategori cukup sebanyak 1 guru atau 7\%, turun dari siklus I yaitu 3 guru atau 20\%, kategori kurang sebanyak 0 guru atau $0 \%$ turun dari siklus I yaitu 1 guru atau 7\%. Sedangkan pengkategorian masing aspek dapat dilihat pada tabel sebagai berikut:

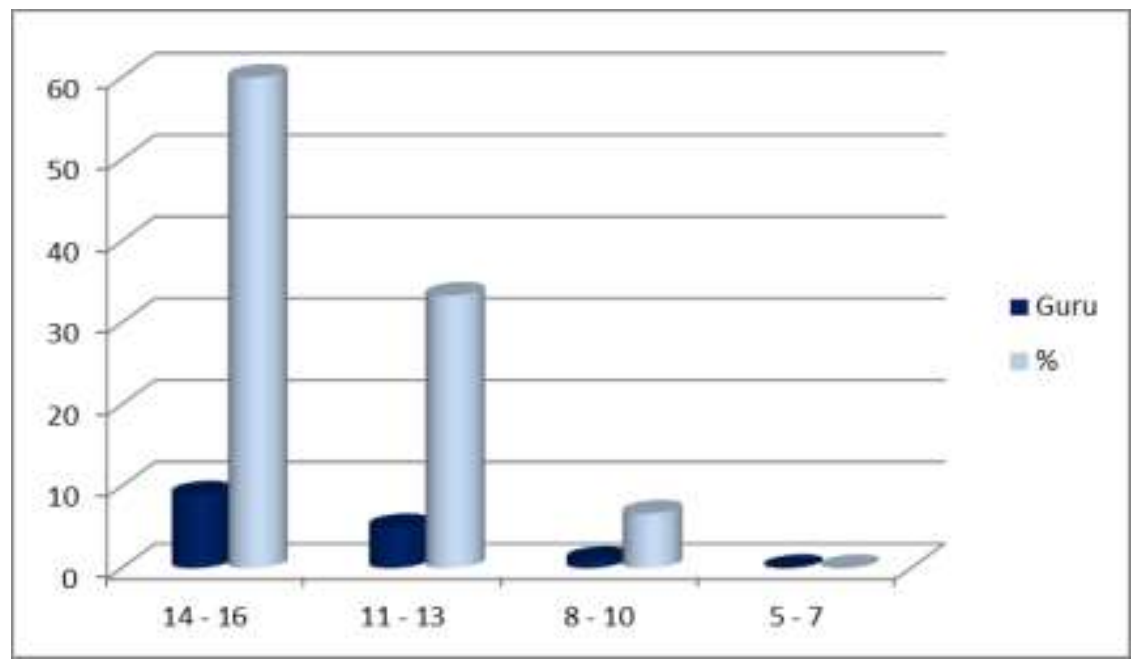

Gambar 2, Diagram Batang Mini Workshop Siklus II

Dari tabel dan diagram di atas menunjukkan aktivitas guru dalam mini workshop sudah baik dan rata-rata guru sangat antusias dalam mengikuti mini workshop

\section{PEMBAHASAN}

Berdasarkan hasil penelitian secara keseluruhan peningkatan profesionalitas guru dalam menyusun perangkat pembelajaran berbanding lurus dengan peningkatan aktivitas guru dalam mengikuti mini workshop, maka dari hasil pembahasan dapat diketahui data terjadi 
peningkatan profesionalitas guru dalam menyusun perangkat pembelajaran setelah dilakukan workshop mini. Untuk memperjelas pembahasan tersebut dapat dilihat data sebagai berikut:

1. Profesionalitas Guru dalam Menyusun Perangkat Pembelajaran

Profesionalitas guru dalam menyusun perangkat pembelajaran SDN Dadapsari Korsatpen Semarang Utara kota Semarang tahun Pelajaran 2020/2021 terjadi peningkatan per siklusnya, untuk lebih jelasnya dapat di lihat dalam tabel dan grafik berikut:

Tabel 5. Perbandingan Kategori Profesionalitas Guru dalam Menyusun Perangkat Pembelajaran Siklus I dan Siklus II

\begin{tabular}{|c|c|c|c|c|c|}
\hline \multirow{2}{*}{ Kategori } & \multirow{2}{*}{ Angka } & \multicolumn{2}{|c|}{ Siklus I } & \multicolumn{2}{c|}{ Siklus II } \\
\cline { 3 - 6 } & & Siswa & $\%$ & Siswa & $\%$ \\
\hline Baik Sekali & $90 \%-100 \%$ & 4 & $27 \%$ & 8 & $53 \%$ \\
\hline Baik & $70 \%-89 \%$ & 6 & $40 \%$ & 6 & $40 \%$ \\
\hline Cukup & $50 \%-69 \%$ & 5 & $33 \%$ & 1 & $7 \%$ \\
\hline Kurang & $\leq 49 \%$ & 0 & $0 \%$ & 0 & $0 \%$ \\
\hline \multicolumn{2}{|c|}{ Jumlah } & 15 & $100 \%$ & 15 & $100 \%$ \\
\hline
\end{tabular}

Berdasarkan tabel dan grafik di atas menunjukkan Profesionalitas guru dalam menyusun perangkat pembelajaran pada siklus I ada 10 guru atau $67 \%$ dan pada siklus II ada 14 siswa atau 93\%, hasil tersebut sudah mencapai indikator yang ditentukan yaitu terjadi peningkatan Profesionalitas guru dalam menyusun perangkat pembelajaran di SDN Dadapsari Korsatpen Semarang Utara kota Semarang tahun Pelajaran 2020/2021 dengan pelaksanaan mini workshop pada siklus I, siklus II tiap individu yang mencapai $90 \%$ dari seluruh jumlah guru.

Berdasarkan hasil penelitian dari perangkat pembelajaran guru yang telah dikemukakan di atas, pada pelaksanaan tindakan siklus I dan siklus II dapat diketahui perubahan-perubahan hasil peningkatan profesionalitas guru dalam menyusun perangkat pembelajaran di SDN Dadapsari Korsatpen Semarang Utara kota Semarang tahun Pelajaran 2020/2021.

\section{Aktivitas Guru dalam Mini Workshop}

Aktivitas guru SDN Dadapsari Korsatpen Semarang Utara kota Semarang dalam mini workshop mengalami kenaikan per siklusnya, untuk lebih jelasnya dapat dilihat dalam tabel dan grafik berikut: 
Tabel 5. Aktivitas guru dalam Mini Workshop Siklus I dan Siklus II

\begin{tabular}{|c|c|c|c|c|c|}
\hline \multirow{2}{*}{$\begin{array}{c}\text { Jumlah } \\
\text { Keaktifan }\end{array}$} & \multicolumn{2}{|c|}{ Siklus I } & \multicolumn{2}{c|}{ Siklus II } & \multirow{2}{*}{ Kategori } \\
\cline { 2 - 5 } & Siswa & $\%$ & Siswa & $\%$ & \\
\hline $14-16$ & 5 & $33 \%$ & 9 & $60 \%$ & Sangat Aktif \\
\hline $11-13$ & 6 & $40 \%$ & 5 & $33 \%$ & Aktif \\
\hline $8-10$ & 3 & $20 \%$ & 1 & $7 \%$ & Cukup \\
\hline $5-7$ & 1 & $7 \%$ & 0 & $0 \%$ & Kurang \\
\hline Jumlah & 15 & $100 \%$ & 15 & $100 \%$ & \\
\hline
\end{tabular}

Berdasarkan tabel dan grafik di atas menunjukkan aktivitas guru SDN Dadapsari Korsatpen Semarang Utara kota Semarang dalam mini workshop pada siklus I ada 11 siswa atau $77 \%$ dan siklus II ada 14 siswa atau 93\%, hasil tersebut sudah mencapai indikator yang ditentukan yaitu terjadi peningkatan aktivitas guru SDN Dadapsari Korsatpen Semarang Utara kota Semarang dalam mini workshop tiap individu pada kategori baik dan sangat baik yang mencapai $90 \%$ dari seluruh jumlah guru.

Hasil tabel di atas juga menunjukkan usaha yang dilakukan kepala sekolah dalam pelaksanaan mini workshop bagi peningkatan profesionalitas guru dalam menyusun perangkat pembelajaran di SDN Dadapsari Korsatpen Semarang Utara kota Semarang tahun Pelajaran 2020/2021 dengan tindakan sekolahnya telah dapat meningkatkan profesionalitas guru dalam menyusun perangkat pembelajaran di SDN Dadapsari Korsatpen Semarang Utara kota Semarang tahun Pelajaran 2020/2021, fokus tindakan kepala yang dilakukan dengan menjadi seorang motivator dan pembimbing yang baik bagi guru..

Hasil ini sesuai dengan pendapat Sumarno, (2012:58-59) yang menyatakan Aktivitas workshop ini juga sangat bermanfaat untuk meningkatkan kualifikasi profesi mereka yang sesuai dengan bidang kerjanya. Artinya, kegiatan workshop mampu memberikan manfaat serta meningkatkan kemampuan dan juga kualitas seseorang.

\section{SIMPULAN}

Dari hasil penelitian dan pembahasan dapat diambil kesimpulan sebagai berikut :

1. Pelaksanaan mini workshop bagi peningkatan profesionalitas guru dalam menyusun perangkat pembelajaran di SDN Dadapsari Korsatpen Semarang Utara kota Semarang tahun Pelajaran 2020/2021 dilakukan dengan memberikan materi kepada guru tentang cara menyusun perangkat pembelajaran yang baik, memberikan contoh reeiel, mempersilahkan guru untuk latihan dan berdiskusi menyusun perangkat yang baik dan hasilnya diskusikan 
bersama dan hasil perangkat pembelajaran yang dilakukan guru dinilai dan jika ditemukan kesalahan maka dilakukan perbaikan

2. Pelaksanaan mini workshop dapat meningkatkan peningkatan profesionalitas guru SDN Dadapsari Korsatpen Semarang Utara kota Semarang tahun Pelajaran 2020/2021dalam menyusun perangkat pembelajaran, hal ini dapat dilihat dari peningkatan hasil profesionalias guru dalam pengelolaan administrasi kelas per siklus dimana pada siklus I ada 10 guru atau 67\% dan pada siklus II ada 14 siswa atau 93\%. Hasil tersebut menunjukkan bahwa hasil tersebut sesuai dengan yang diharapkan. Peningkatan juga terjadi pada aktivitas guru dalam mengikuti mini worskhsop dimana pada siklus I ada 11 siswa atau $77 \%$ dan siklus II ada 14 siswa atau 93\%. Peningkatan tersebut pelaksanaan mini workshop menjadi salah satu cara yang efektif bagi kepala sekolah dalam meningkatkan kemampuan guru dalam menyusun perangkat pembelajaran

\section{SARAN}

Ada beberapa saran yang hendak penulis sampaikan, yaitu:

1. Guru hendaknya menyusun perangkat pembelajaran sendiri meskipun masih dalam taraf belajar dan guru harus menyusun perangkat pembelajaran secara berkala/kontinyu pada waktu selesai mengajar maupun pada kegiatan mini workshop ini sehingga proses belajar mengajar yang dirancang dapat diterapkan pada peserta didik dan diharapkan dapat meningkatkan hasil belajar peserta didik

2. Kepala sekolah harus lebih sering mengadakan kegiatan mini workshop guna meningkatkan profesionalitas guru guru khususnya profesionalitas dalam menyusun perangkat pembelajaran maupun proses pembelajaran sehingga diharapkan dapat berdampak pada mutu pembelajaran di kelas;

3. Sekolah diharapkan melaksanakan kegiatan atau program peningkatan profesionalitas guru sehingga wawasan dan pengetahuan guru mengenai dunia pendidikan dapat bertambah dan secara otomatis akan berdampak pada mutu pendidikan di sekolah

4. Bagi peneliti lain dapat melaksanakan penelitian yang lebih lanjut, penelitian ini juga dapat dikembangkan kegiatan mini workshop dengan pembahasan yang lain dalam upaya meningkatkan profesionalitas guru.

\section{DAFTAR PUSTAKA}

Anwar, Moch. Idochi, 2013, Administrasi Pendidikan dan Manajemen Biaya Pendidikan, Bandung: Alfabeta 
Arikunto, Suharsimi, 1993, Organisasi Administrasi Pendidikan Teknologi dan Kejuruan, Jakarta: PT. Raja Grafindo Persada

Arikunto, Suharsimi. 2010. Prosedur Penelitian Suatu Penelitian Pendekatan PraktekCet.14. Jakarta: Rineka Cipta.

Depdiknas. 2008. Standar Pengembangan: Kelompok Kerja Guru (KKG)-Musyawarah Guru Mata Pelajaran (MGMP). Jakarta: Dirjen PMPTK, Depdiknas.

Kunandar, 2007, Guru Profesional Implementasi Kurikulum Tingkat Satuan Pendidikan KTSP dan Persiapan Menghadapi Sertifikasi Guru, Jakarta: Rajawali Pers

Mulyasa, 2006, Kurikulum Tingkat Satuan Pendidikan Sebuah Panduan Praktis, Bandung: Remaja Rosda Karya, 2006

Mulyasa, 2013, Manajemen Berbasis Sekolah, Bandung: Remaja Rosdakarya

Mulyasa, E., 2013, Menjadi Kepala Sekolah Profesional dalam Koneks Menyukseskan MBS dan $K B K$, Bandung: Remaja RosdaKarya

Nawawi, Hadari, 2008, Kepemimpinan menurut Islam, Yogyakarta: Gadjah Mada University Press

Nazarudin. 2011. Manajemen Pembelajaran: Implementasi Konsep, Karakteristik, dan Metodologi Pendidikan Agama Islam. Yogyakarta: Sukses Offset.

Purwanto, Ngalim, 2010, Administrasi Pendidikan, Jakarta: Mutiara

Rohani, Ahmad dan Abu Ahmadi, 2010, Pedoman Penyelenggaran Administrasi di Sekolah, Jakarta: Bumi Aksara

Sagala, Syaiful. 2010. Supervisi Pengajaran dalam Profesi Pendidikan. Bandung:Alfabeta.

Sahertian, A. Piet. 2010. Konsep Dasar dan Teknik Supervisi Pendidikan. Jakarta: Rineka Cipta.

Sanjaya, Wina. 2010. Perencanaan dan Desain Sistem Pembelajaran. Jakarta: Kencana Prenada Media Group.

Sardiman , 2006, Interaksi dan Motivasi Belajar Mengajar, Jakarta: Rajawali

Slamet PH, 2012, Kepemimpinan Kepala Sekolah, Makalah dan Lokakarya Nasional

Soetopo, Hendiyat dan Wasty Sumanto, 2014, Kepemimpinan dan Supervisi Pendidikan, Yogyakarta: Bina Aksara

Sugiyono, 2013, Metodologi Penelitian Pendidikan Pendekatan Kuantitatif, Kualitatif dan $R \& D$, Bandung: Alfabeta 
Sumarno. 2012. Pengembangan Sumber Daya Manusia Melalui Kegiatan Workshop.Jakarta: Erlangga.

Supriadi, Dedi, 1999, Mengangkat Citra dan Martabat Guru, Yogyakarta: Adicipta Karya Nusa

Suryosubroto, B., 2012, Proses Belajar Mengajar di Sekolah, Jakarta : Rineka Cipta

Tim Penyusun Undang-undang No. 14/2005, Tentang Guru dan Dosen

Undang-Undang Republik Indonesia, Nomor 14 Tahun 2005, Tentang Guru dan Dosen, Bab I Pasal 1 Ayat 1, peraturan pemerintah RI Nomor 74 Tahun 2008, Bab I Pasal I Ayat I, Bandung: CV. Nuansa Aulia, 2009

Undang-Undang Republik Indonesiai, Nomor 20 Tahun 2003, Tentang Sisdiknas, Bab IX, Pasal.39 Ayat 2e Bandung: Fokus Media, 2009

Wahyosumidjo, 2011, Kepemimpinan Kepala Sekolah Tinjauan Teoritik dan Permasalahannya, Jakarta: Raja Grafindo Persada

Widodo, S. Chomsin \& Jasmadi. 2008. Panduan Menyusun Bahan Ajar Berbasis Kompetensi. Jakarta: PT. Elex Media Kompetindo. 